\title{
CARBON STOCKS IN A 20-YEAR-OLD CONIFEROUS PLANTATION - A CASE STUDY IN FANDOGHLOO REGION, NORTHWESTERN IRAN
}

\author{
FATAEI, E. $^{1^{*}}-$ VARAMESH, . $^{2}$ \\ ${ }^{l}$ Department of Environmental sciences, Ardabil Branch, Islamic Azad University, Ardabil, \\ Iran. \\ ${ }^{2}$ Elits and Young Researchers Club, Ardabil Branch, Islamic Azad University, Ardabil, Iran. \\ *Corresponding author: Ebrahim Fataei \\ address: Department of Environmental sciences, Basic Sciences Faculty, Basij Square, Ardabil \\ Branch, Islamic Azad University, Ardabil, Iran. Postal Code: 5615731567. \\ e-mail:ebfataei@gmail.com \\ fax: +98-453-372-9820 \\ (Received $11^{\text {th }}$ Oct 2015; accepted $21^{\text {st }}$ Mar 2016)
}

\begin{abstract}
In Fandoghloo region, northwestern Iran, tree plantations were established on a degraded rangeland, which was previously mainly used for grazing. We assessed the above- and belowground ecosystem biomass and carbon (C) pools of pure and mixed Pinus nigra, Cedeus libani and Picea abies plantation stands (20 years-old) in Ardabil, Iran. Biomass and C stocks of above- and belowground tree biomass and litter were determined from plot-level inventories. Mineral soil C stocks were estimated from soil cores at three depths $0-15,15-30$ and $30-50 \mathrm{~cm}$. Our results showed an increase in the total ecosystem carbon stock after the afforestation. The highest total carbon stock was $55.57 \mathrm{Mg} \mathrm{ha}^{-1}$ in the mixed $P$. nigra - C. libani and it was $25.006 \mathrm{Mg} \mathrm{ha}^{-1}$ in the degraded rangeland. The carbon stock in the aboveground biomass ranged from $2.4 \mathrm{Mg} \mathrm{ha}^{-1}$ in the degraded rangeland to $19.28,15.1,6.17,4.55$, and $3.87 \mathrm{Mg} \mathrm{ha}^{-1}$ in the P.nigra - C. libani, P.nigra, P. abies- P.nigra, C. libani and P. abies stands, respectively. The amount of litter carbon stock ranged from $0.53 \mathrm{Mg} \mathrm{ha}^{-1}$ in the degraded rangeland to $3.51,3.06,2.03,1.55,1.41 \mathrm{Mg} \mathrm{ha}^{-1}$ in the P. abies- P.nigra, P.nigra-C. libani, P.nigra, C. libani and $P$. abies stands, respectively. The soil carbon stock increased from 21.41 to $30.11,28.58,28.41,27.45$ and $25.43 \mathrm{Mg} \mathrm{ha}^{-1}$ in the C. libani, P.nigra, P.nigra - C. libani, P. abies - P.nigra and P. abies stands, respectively. Significant interactions were observed between stand and soil depth on carbon stock after rangeland afforestation with coniferous species. Aboveground tree biomass became the major ecosystem $\mathrm{C}$ pool. The difference in total ecosystem $\mathrm{C}$ between the degraded rangeland and mixed P.nigra - C. libani stand was $30.56 \mathrm{Mg} \mathrm{ha}^{-1}$. The highest SOC accumulation was observed in the surface layer of the C. libani $\left(34.95 \mathrm{Mg} \mathrm{ha}^{-1}\right)$, but the accumulation rate is species dependent. Our results highlight the importance of coniferous plantations on degraded rangeland that will most probably increase the rate of $\mathrm{C}$ sequestration and thereby mitigate the negative effects of increasing atmospheric $\mathrm{CO}_{2}$ concentrations. As a matter of fact, the selection of appropriate species and plantation will be considered in the next afforestation projects.
\end{abstract}

Keywords: carbon sequestration, pure and mixed plantations, Pinus nigra, Cedeus libani, Picea abies

\section{Introduction}

Nowadays humanity faces important global challenges in the form of climate change, which is a result of increasing greenhouse gases (GHGs), mainly carbon dioxide $\left(\mathrm{CO}_{2}\right)$ (Nakakaawa et al., 2010). Biomass and soil are considered to have a large potential for temporary and long-term carbon (C) storage (Gower, 2003; Houghton, 2005). Enhancing $\mathrm{C}$ sequestration by increasing forested land area (e.g. afforestation) has been suggested as an effective factor to mitigate elevated atmospheric carbon dioxide $\left(\mathrm{CO}_{2}\right)$ concentrations and hence contribute towards the prevention of global warming (Watson, 
2000; IPCC, 2001). The United Nations Framework Convention on Climate Change (UNFCCC) also promotes afforestation programs as strategies to reduce net $\mathrm{CO}_{2}$ emissions (UNFCCC, 1997). The study of the effects of afforestation on the ecosystem carbon stock has been widely reported in the recent years (Zinn et al., 2002; Lemma et al., 2006; Nosetto et al., 2006; Yüksek and Yüksek, 2011; Hansson et al., 2013; Zhag et al., 2013; Varamesh et al., 2014), although the contribution of afforestation was known in biomass carbon sequestration, the effects of tree plantation on soil carbon stock were less certain because of effective factors such as rainfall, soil texture, stand age (Guo and Gifford, 2002; Paul et al., 2002). However, reports from various studies on the effects of afforestation on net SOC accretion are inconsistent. Due to these inconsistencies, more studies seem needed to evaluate the potential of SOC accumulation under productive plantation forests on degraded rangelands (Varamesh et al., 2014). The afforestation could be a very useful method for restoring degraded soils and ecosystems (IPCC, 2000) and in the global scale, this method is considered as soil conservation, desertification, and an increase of carbon sequestration (Grunzweig et al., 2003; Kumar et al., 2001; Maestre and Cortina, 2004; Nosetto et al., 2006). Giuffre et al. (2003) obtained significant differences by evaluating of soil organic carbon between the afforested regions compared with the rangeland in the Patagonia, Argentina. Nosetto et al. (2006) found that the afforestation with Pinus ponderosa in grassland of Patagonia increases above- and belowground carbon stocks, and Mireia et al. (2010) noted a significant increase in soil organic carbon in the plantation of Pinus halepensis. Fonseca et al. (2012) found that carbon in the biomass was over $78 \mathrm{Mg} / \mathrm{ha}$ but the soil represents the main carbon sink at an ecosystem level with more than $85 \mathrm{Mg} / \mathrm{ha}$. Mean annual increments for carbon in the biomass was above $5.3 \mathrm{Mg} / \mathrm{ha}$ and over $1.3 \mathrm{Mg} / \mathrm{ha}$ in the soil. Heras et al. (2013) claimed that in the short-term, the carbon stored in the live biomass at afforested stand level was reduced, but the positive effect on productivity permits to restore and exceed the initial amount of carbon in the medium-term.

Among the different ecosystems, coniferous forests were considered as great resources of carbon stocks (Gucinski et al., 1995). Several researchers (Akala and Lal, 2001; Xiao-Wen et al., 2009) have focused on the importance of afforstration and suitable species selection to enhance the carbon sequestration. Thus attention to forest ecosystem compartments contribution in carbon sequestration is important, because it is essential to understand the potential of carbon sequestration of forest ecosystem to consider complex of trees, understory, soil and litter (Uri et al., 2012).

The Pinus nigra, Cedrus libani, and Picea abies are known for afforstation in Iran. However, there are few studies about the effects of afforestation on the total carbon stock of ecosystem with these species in the degraded rangelands of Iran. As a result, specific objectives were to investigate the distribution of carbon stuck in the compartments (soil, above-, belowground biomass and litters) of coniferous planted stands and degraded rangelands, assess the depth distribution of SOC concentration up to $50 \mathrm{~cm}$ depth, determine the trends and variations in $\mathrm{C}$ pool at the scale of the plantation and establish the association of SOC with selected physical and chemical soil properties. The basic assumption of this study was relatively homogeneous biophysical conditions of the stands. 


\section{Materials and Methods}

\section{Study area}

The study area is located in the northwest of Iran (northeast of Ardabil), between latitudes $38^{\circ} 22^{\prime}$ and $38^{\circ} 24^{\prime} \mathrm{N}$ and longitudes $48^{\circ} 31^{\prime}$ and $48^{\circ} 34^{\prime} \mathrm{E}$ (Fig. 1). It covers an area of about 50 ha. According to Namin Meteorological Station, the mean annual precipitation and temperature were $379 \mathrm{~mm}$ and $8.8^{\circ} \mathrm{C}$, respectively. The elevation of the forested area ranges from 1350 to $1500 \mathrm{~m}$ above sea level. The study area includes pure and mixed Pinus nigra, Cedeus libani and Picea abies plantation stands. In the past, afforested areas were barren lands which were previously mainly used for grazing and were planted with the mentioned species almost 20 years ago. The soil texture of the area is loam and clay loam.

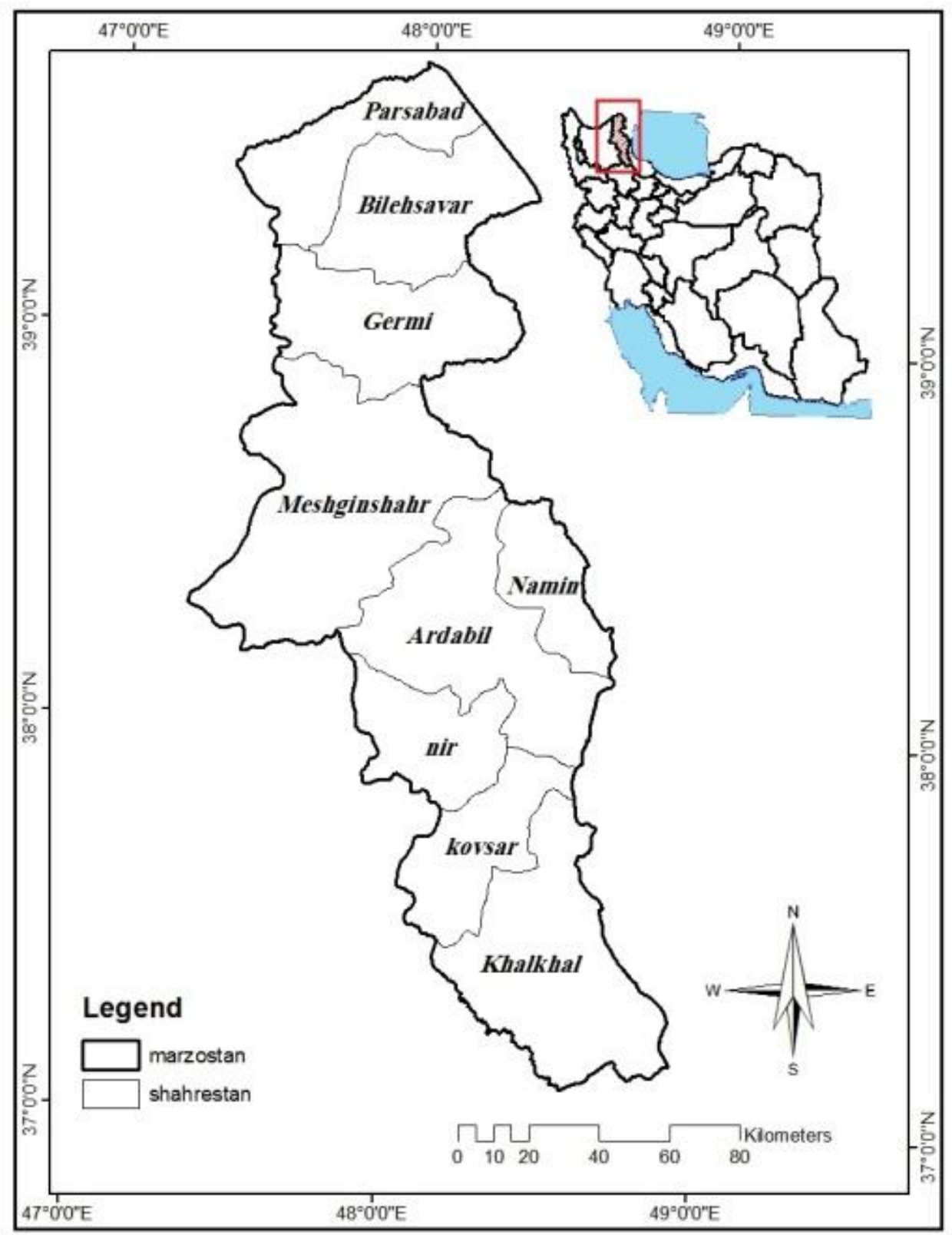

Figure 1. Study area 


\section{Sampling and inventory method of soil litter and trees}

10 hectare areas were selected for each stand and in order to decrease the bordering effects, surrounding rows of stands were not considered during sampling (Varamesh et al., 2014). In order to characterize carbon storage and distribution, we sampled soil and litter pools where organic carbon accumulates. To evaluate carbon stocked in tree compartments we used tree allometric equations. Sampling and inventory were carried out during October (2013) using a randomly systematic method from six $400 \mathrm{~m}^{2}$ squares (20 x $20 \mathrm{~m}$ ) in each type of plantation system, i.e. Picea abies, Cedrus libani and Pinus nigra.

\section{Calculation of above- and belowground biomass}

In $20 \times 20 \mathrm{~m}$ plots, quantitative properties of all trees within the plot were measured including diameter at breast height $(\mathrm{DBH})$, total height $(\mathrm{H})$ and trunk height $(\mathrm{HC})$, and two perpendicular diameters of the canopy ( $\mathrm{W}$ and $\mathrm{L})$. Other reservoirs, like fine roots, fruits, coarse woody debris or understorey species, were considered negligible and therefore, not measured.

To calculate tree biomass and to compute trunk, canopy and root volume, the following steps were done according to prescription (Hernandez et al., 2004):

First, the basal area of tree was computed using Equation 1, and then the tree volume was gained using Equation 2. Finally, the biomass of trunk (kilogram) was computed according to the Equation 3.

$$
A b=\pi x r^{2}
$$

Where $\pi=3.1415927$ and $r$ is the radius of the tree at breast height $(0.5 \mathrm{DBH})$.

$$
V=A b \times H \times K c
$$

Where, $\mathrm{Ab}$ is the basal area; $\mathrm{H}$ is the height, and $\mathrm{Kc}$ is a site-dependent constant in standard cubing practice used in forest inventory (0.5463).

$$
\text { Biomass }=V \times W D \times 1000
$$

$\mathrm{V}=$ volume of the trunk. WD= wood density.

Since the full sampling of tree roots is time demanding and expensive and also in order to avoid destructive sampling methods, the root biomass was calculated using Equation number 4 (Hernandez et al., 2004):

$$
B G B=\text { Volume } A G B \times 0.2
$$

$\mathrm{BGB}=$ Belowground biomass. $\mathrm{AGB}=$ Aboveground biomass.

The canopy volume of trees was computed by the Equation 5 .

$$
V\left(m^{3}\right)=\frac{\Pi \times D b^{2}}{12}
$$


Note: $\pi=3.141592 ; \mathrm{Db}=$ diameter of the crown (to calculate $\mathrm{Db}$, the average of the field measurements $\mathrm{L}$ and $\mathrm{W}$ is taken and used as the diameter of the crown: $\mathrm{Db}=(\mathrm{L}+$ $\mathrm{W}) / 2$ ); $\mathrm{Hc}=$ height from the ground to the base of the crown.

The carbon Stock of biomass was calculated based on Equation 6. below:

$$
\mathrm{C}=0.55 \times \text { Biomass }_{(\text {total }}
$$

\section{Soil and litter sampling}

Four soil profiles were dug in the four corners of the $400 \mathrm{~m}^{2}$ plot, then soil samples were collected at 0-15, 15-30, and 30-50 cm depths using a core (Ø $35 \mathrm{~mm}$ ) sampler, thus resulting in 72 soil samples for each stand at three different depths. For calculation of the soil carbon, nitrogen and phosphorus storage, bulk density of soil was determined. From the soil pit, bulk density samples were taken from different soil layers $(0-50 \mathrm{~cm})$ with a stainless steel cylinder $\left(\mathrm{d}=40 \mathrm{~mm}\right.$ and volume $\left.=50 \mathrm{~cm}^{3}\right)$ avoiding compression of the soil and preserving soil structure (Uri et al., 2012). Litter was removed from each profile, as well as, large plant material (e.g. root and shoots) occurring in each soil sample. Then soil samples were air-dried and $2 \mathrm{~mm}$ sieved (Lemma, et al., 2006). Litter, as well as grass, shrubs and forbs biomass was collected in $0.25 \mathrm{~m}^{2}$ plots $\left(0.5 \times 0.5 \mathrm{~m}^{2}\right)$. Sub samples of each compartment were oven dried and the dry matter coefficients were used to transform fresh weight into dry matter.

The organic carbon content of litter was calculated by the following Equation (7):

$$
\mathrm{OC}=1 / 2 \times \mathrm{OM}
$$

\section{Laboratory analysis}

Dry bulk density was calculated by dividing the oven dry mass at $\left(105^{\circ} \mathrm{C}\right)$ of the $<2$ $\mathrm{mm}$ fraction by the volume of the core. The soil texture was determined by the Bouyoucos hydrometer method (Bouyoucos, 1962). Soil $\mathrm{pH}$ was determined potentiometrically in a 1:2.5 (v/v) soil:water suspension. Electrical conductivity (EC) was characterized with (soil:water ratio, 1:2). For testing of total $\mathrm{N}$ (Kjeldahl) in the soil samples, Tecator ASN 3,313 was employed. Available phosphorus (ammonium lactate extractable) in the soil was determined by flow injection analysis using Tecator ASTN 9/84 and total organic $\mathrm{C}$ determined by the Walkey and Black method.

The total SOC $\left(\mathrm{Mg} \mathrm{ha}^{-1}\right)$ stock within a certain soil layer was calculated according to the following equation (Lemma et al., 2006):

$$
\operatorname{SOC}\left(\mathrm{Mg} \mathrm{ha}^{-1}\right)=\operatorname{SOC}\left(\mathrm{g} \mathrm{kg}^{-1}\right) \mathrm{z}_{\mathrm{b}} 10
$$

Where, $\mathrm{z}$ is soil layer thickness $(\mathrm{m})$, and $\mathrm{p}_{\mathrm{b}}$ is dry bulk density $\left(\mathrm{Mg} \mathrm{m}^{-3}\right)$.

\section{Statistical analysis}

All of data were analyzed using the SPSS 19.0. The variable normality test was checked by the Kolmogorov-Smirnov test, meanwhile, Levene's test was used to examine the equality of the variances. Differences in soil characteristics among afforested stands and depths were tested with two-way analysis (ANOVA) using the General Linear Model (GLM) procedure, with different stands and depths (0-15, 15- 
30, and 30-50 cm) as independent factors. Interactions between independent factors were also tested. Duncan's test was used to separate the averages of the dependent variables which were significantly affected by treatment. Significant differences among treatment averages for different parameters were tested at $\mathrm{p} \leq 0.05$.

Some selected physico-chemical properties of the soil are presented in Table 1. Soil $\mathrm{pH}\left(\mathrm{H}_{2} \mathrm{O}, 1: 1\right)$ ranges from 5.43 to 5.85 and $\mathrm{EC}$ ranges from 0.1 to $0.0063 \mathrm{dS} \mathrm{m}^{-1}$. Soil texture was loam in $P$. nigra stand and clay-loam in the other stands. The increase in bulk density with increasing depth was gained in more stands.

Table 1. Some soil properties in stands and Rangeland

\begin{tabular}{|c|c|c|c|c|c|c|c|}
\hline \multirow{2}{*}{ Soil properties } & \multirow{2}{*}{ 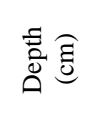 } & \multicolumn{6}{|l|}{ Stand } \\
\hline & & Pinus & Cedrus & Picea abies & Pinus-Cedrus & Picea-Pinus & Rangeland \\
\hline \multirow[t]{3}{*}{$\mathrm{PH}_{\mathrm{H} 2 \mathrm{O}}$} & $0-15$ & $5.63 \pm 0.03$ & $5.85 \pm 0.13$ & $5.49 \pm 0.058$ & $5.81 \pm 0.05$ & $5.51 \pm 0.05$ & $5.53 \pm 0.07$ \\
\hline & $15-30$ & $5.65 \pm 0.03$ & $5.40 \pm 0.026$ & $5.54 \pm 0.086$ & $5.83 \pm 0.12$ & $5.45 \pm 0.01$ & $5.72 \pm 0.1$ \\
\hline & $30-50$ & $5.50 \pm 0.03$ & $5.43 \pm 0.0066$ & $5.59 \pm 0.057$ & $5.62 \pm 0.07$ & $5.61 \pm 0.0057$ & $5.71 \pm 0.06$ \\
\hline \multirow{3}{*}{$\begin{array}{r}\text { Bulk density } \\
\qquad\left(\mathrm{g} / \mathrm{cm}^{-3}\right)\end{array}$} & $0-15$ & $1.44 \pm 0.003$ & $1.51 \pm 0.0033$ & $1.49 \pm 0.030$ & $1.54 \pm 0.078$ & $1.41 \pm 0.003$ & $1.37 \pm 0.041$ \\
\hline & $15-30$ & $1.51 \pm 0.003$ & $1.50 \pm 0.012$ & $1.55 \pm 0.041$ & $1.62 \pm 0.05$ & $1.31 \pm 0.006$ & $1.50 \pm 0.044$ \\
\hline & $30-50$ & $1.61 \pm 0.009$ & $1.53 \pm 0.0003$ & $1.59 \pm 0.036$ & $1.46 \pm 0.015$ & $1.53 \pm 0.003$ & $1.57 \pm 0.050$ \\
\hline \multirow[t]{3}{*}{$\mathrm{EC}\left(\mathrm{dS} \mathrm{m}^{-1}\right)$} & $0-15$ & $0.023 \pm 0.0007$ & $0.0063 \pm 0.0012$ & $0.02 \pm 0.0023$ & $0.022 \pm 0.0006$ & $0.02 \pm 0.0007$ & $0.02 \pm 0.003$ \\
\hline & $15-30$ & $0.031 \pm 0.0006$ & $0.0073 \pm 0.0003$ & $0.02 \pm 0.0026$ & $0.021 \pm 0.0037$ & $0.02 \pm 0.0003$ & $0.03 \pm 0.337$ \\
\hline & $30-50$ & $0.018 \pm 0.0003$ & $0.011 \pm 0.0033$ & $0.02 \pm 0.0023$ & $0.021 \pm 0.0012$ & $0.01 \pm 0.0003$ & $0.03 \pm 0.003$ \\
\hline \multirow[t]{3}{*}{ Sand $(\%)$} & $0-15$ & $25.67 \pm 0.3$ & $28.33 \pm 0.88$ & $33.42 \pm 1.82$ & $25.33 \pm 2.33$ & $26.33 \pm 0.33$ & $40.33 \pm 4.26$ \\
\hline & $15-30$ & $29.67 \pm 0.3$ & $26.00 \pm 0.21$ & $33.75 \pm 2.25$ & $35.00 \pm 0.31$ & $29.00 \pm 0.58$ & $44.33 \pm 7.17$ \\
\hline & $30-50$ & $29.67 \pm 2.18$ & $31.00 \pm 0.57$ & $32.92 \pm 2.43$ & $29.00 \pm 1$ & $29.33 \pm 0.33$ & $38 \pm 4.51$ \\
\hline \multirow[t]{3}{*}{ Clay (\%) } & $0-15$ & $32.00 \pm 0.6$ & $31.00 \pm 0.57$ & $28.17 \pm 1.13$ & $32.33 \pm 1.20$ & $31.00 \pm 0.58$ & $23.67 \pm 0.33$ \\
\hline & $15-30$ & $28.67 \pm 0.33$ & $30.67 \pm 0.66$ & $28.67 \pm 1.16$ & $28.33 \pm 0.33$ & $31.67 \pm 0.33$ & $21 \pm 1.0$ \\
\hline & $30-50$ & $31.67 \pm 0.33$ & $27.33 \pm 0.33$ & $30.33 \pm 1.01$ & $32.67 \pm 1.20$ & $34.00 \pm 0.25$ & $22.33 \pm 2.6$ \\
\hline \multirow[t]{3}{*}{ Silt (\%) } & $0-15$ & $42.33 \pm 0.7$ & $40.67 \pm 0.33$ & $38.42 \pm 1.81$ & $42.33 \pm 1.20$ & $42.67 \pm 0.33$ & $36 \pm 4.58$ \\
\hline & $15-30$ & $41.67 \pm 0.33$ & $43.33 \pm 0.66$ & $37.58 \pm 1.42$ & $36.67 \pm 0.33$ & $39.33 \pm 0.67$ & $34.67 \pm 7.7$ \\
\hline & $30-50$ & $38.67 \pm 1.85$ & $41.67 \pm 0.33$ & $36.75 \pm 2.14$ & $38.33 \pm 0.33$ & $36.67 \pm 0.33$ & $39.67 \pm 6.7$ \\
\hline
\end{tabular}

Values are means $( \pm \mathrm{SE})$ of triplicate soil analysis.

\section{Results}

Some of the quantitative parameters of the stands are given in Table 2. Pure stand of $P$. nigra in most parameters had higher values compared to other stands. The highest amount of trunk height $(\mathrm{m})$ was in the $C$. libani and greatest canopy volume was observed in the P. nigra - C. libani.

Table 2. Stand characteristics of the Pinus nigra, Cedrus, Picea abies, Pinus-Cedrus and Picea- Pinus stands

\begin{tabular}{cccccc}
\hline \multirow{2}{*}{ Stand parameter } & \multicolumn{5}{c}{ Stands } \\
\cline { 2 - 6 } & Pinus nigra & Cedrus & Picea abies & Pinus-Cedrus & Picea- Pinus \\
\hline DBH $(\mathrm{cm})$ & $17.27 \pm 0.305 \mathrm{a}$ & $12.47 \pm 0.018 \mathrm{~d}$ & $13.14 \pm 0.706 \mathrm{c}$ & $15.75 \pm 0.027 \mathrm{~b}$ & $15.67 \pm 0.088 \mathrm{~b}$
\end{tabular}




\begin{tabular}{cccccc} 
Tree height $(\mathrm{m})$ & $7.61 \pm 0.315 \mathrm{a}$ & $6.25 \pm 0.123 \mathrm{~d}$ & $6.96 \pm 0.070 \mathrm{bc}$ & $6.73 \pm 0.093 \mathrm{~cd}$ & $7.28 \pm 0.041 \mathrm{ab}$ \\
Trunk Height $(\mathrm{m})$ & $3.17 \pm 0.018 \mathrm{~d}$ & $3.68 \pm 0.043 \mathrm{a}$ & $3.48 \pm 0.038 \mathrm{~b}$ & $3.28 \pm 0.006 \mathrm{c}$ & $3.28 \pm 0.015 \mathrm{c}$ \\
Canopy volume $\left(\mathrm{m}^{3} / \mathrm{ha}\right)$ & $9.72 \pm 0.069 \mathrm{~b}$ & $3.58 \pm 0.006 \mathrm{~d}$ & $6.54 \pm 1.094 \mathrm{c}$ & $12.49 \pm 0.012 \mathrm{a}$ & $5.73 \pm 0.033 \mathrm{c}$ \\
basal area $\left(\mathrm{m}^{2} / \mathrm{ha}\right)$ & $0.024 \pm 0.000 \mathrm{a}$ & $0.01 \pm 0.000 \mathrm{~d}$ & $0.013 \pm 0.001 \mathrm{~d}$ & $0.02 \pm 0.001 \mathrm{~b}$ & $0.018 \pm 0.000 \mathrm{c}$ \\
Stand volume $\left(\mathrm{m}^{3} / \mathrm{ha}\right)$ & $0.13 \pm 0.015 \mathrm{a}$ & $0.04 \pm 0.003 \mathrm{~d}$ & $0.051 \pm 0.006 \mathrm{~cd}$ & $0.09 \pm 0.001 \mathrm{~b}$ & $0.072 \pm 0.003 \mathrm{bc}$ \\
\hline
\end{tabular}

Values followed by the same letter within a row are not statistically different (Duncan, $\mathrm{P}<0.05$ ).

\section{Total carbon stock in the ecosystem}

The total carbon stock of ecosystem has changed from $25.006 \mathrm{Mg} \mathrm{ha}^{-1}$ in degraded rangeland to $55.57 \mathrm{Mg} \mathrm{ha}^{-1}$ in the mixed P.nigra - C.libani, $49.01 \mathrm{Mg} \mathrm{ha}^{-1}$ in the P.nigra, $38.73 \mathrm{Mg} \mathrm{ha}^{-1}$ in the mixed P.abies - P.nigra, $37.84 \mathrm{Mg} \mathrm{ha}^{-1}$ in the pure C.libani and $31.68 \mathrm{Mg} \mathrm{ha}^{-1}$ in the pure P.abies stands (Fig. 2).

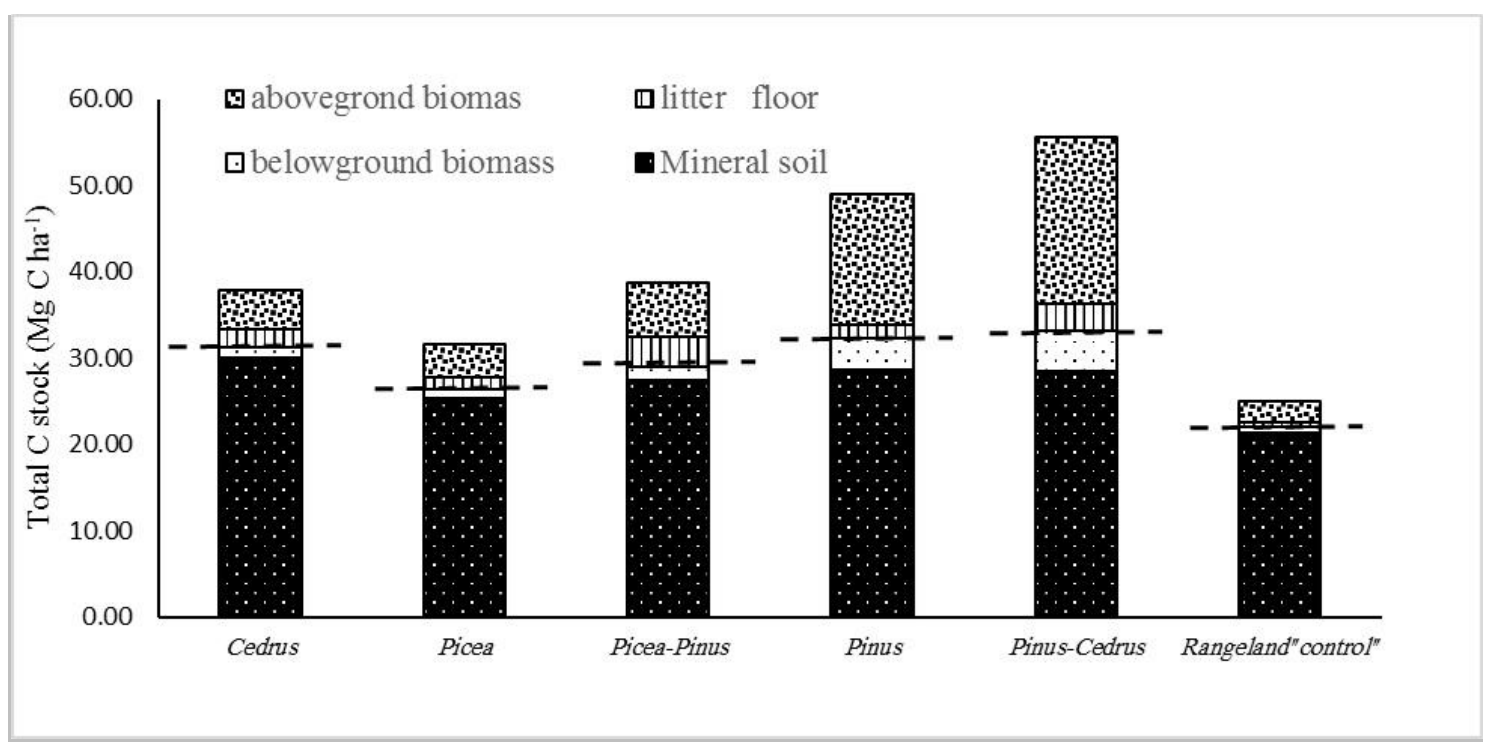

Figure 2. $C$ content of total above- and belowground tree biomass, floor litter, and mineral soil in the stands (dashed line separates above-from belowground C stock)

The carbon stock in the aboveground biomass showed significant increase after the afforestartion in the degraded rangeland ( $\mathrm{p}<0.001$ ), so that it has increased from $2.4 \mathrm{Mg}$ $\mathrm{ha}^{-1}$ in the rangeland to $3.87,4.55,6.17,15.119 .28 \mathrm{Mg} \mathrm{ha}^{-1}$ in the P.nigra - C.libani, P.nigra, P.abies - P.nigra, C.libani and P.abies stands, respectively (Fig. 2). The carbon stock in the belowground biomass showed significantly higher values after degraded rangeland afforestration in all stands $(\mathrm{p}<0.001)$. So, it increased from 0.67 in the degraded rangeland to $1.15,1.60,3.79,4.82$, and $10.97 \mathrm{Mg} \mathrm{ha}^{-1}$ in the P.nigra C.libani, P.nigra, P.abies - P.nigra, C.libani and P.abies stands, respectively (Fig. 2). The carbon stock in the ecosystem litter had the same trend mentioned above. Therefore, a significant difference $(\mathrm{p}<0.001)$ was observed in the carbon stock, the value of which ranged from 0.53 in the rangeland to $1.41,1.55,2.027,3.07,3.51 \mathrm{Mg} \mathrm{ha}^{-}$ ${ }^{1}$ in the P.abies - P.nigra, P.nigra - C.libani, P.nigra, C.libani and P.abies stands, respectively (Fig. 2). The amount of carbon stock in the soils showed significant differences in the range of 21.41 in the rangeland and 25.43, 27.45, 28.41, 28.58, 30.11 
$\mathrm{Mg} \mathrm{ha}{ }^{-1}$ in the C.libani, P.nigra, P.nigra - C.libani, P.abies - P.nigra and P.abies stands, respectively (Fig. 2). In general, the impacts of the degraded rangeland afforestation on the carbon stock in the ecosystem compartments showed significant difference increase.

\section{The carbon stock in the soil}

After rangeland afforestation with coniferous species, significant $(\mathrm{p}<0.05)$ interactions were observed between stand and soil depth carbon stock. In general, the soil carbon stocks increased in all layers, namely upper $(0-15 \mathrm{~cm})$, middle $(15-30 \mathrm{~cm})$ and lower $(30-50 \mathrm{~cm}$ ) layers (Fig. 3). The highest carbon stock in the mineral soil was observed in the surface layer of the $C$. libani $\left(34.95 \mathrm{Mg} \mathrm{ha}^{-1}\right)$, and the middle and lower layer of P. nigra stands (28.98 and $33.23 \mathrm{Mg} \mathrm{ha}^{-1}$, respectively) (Fig. 3). The carbon stock in the upper, middle and lower layer of each stand showed statistically significant differences among the P. nigra, P. abies - P. nigra, and C. libani stands (Fig. 3). The rangeland, $P$. nigra $-C$. libani and $P$. abies stands showed no significant differences in the depths considered. The rangeland afforestation effects on the carbon stock presented differences with the depth changes.

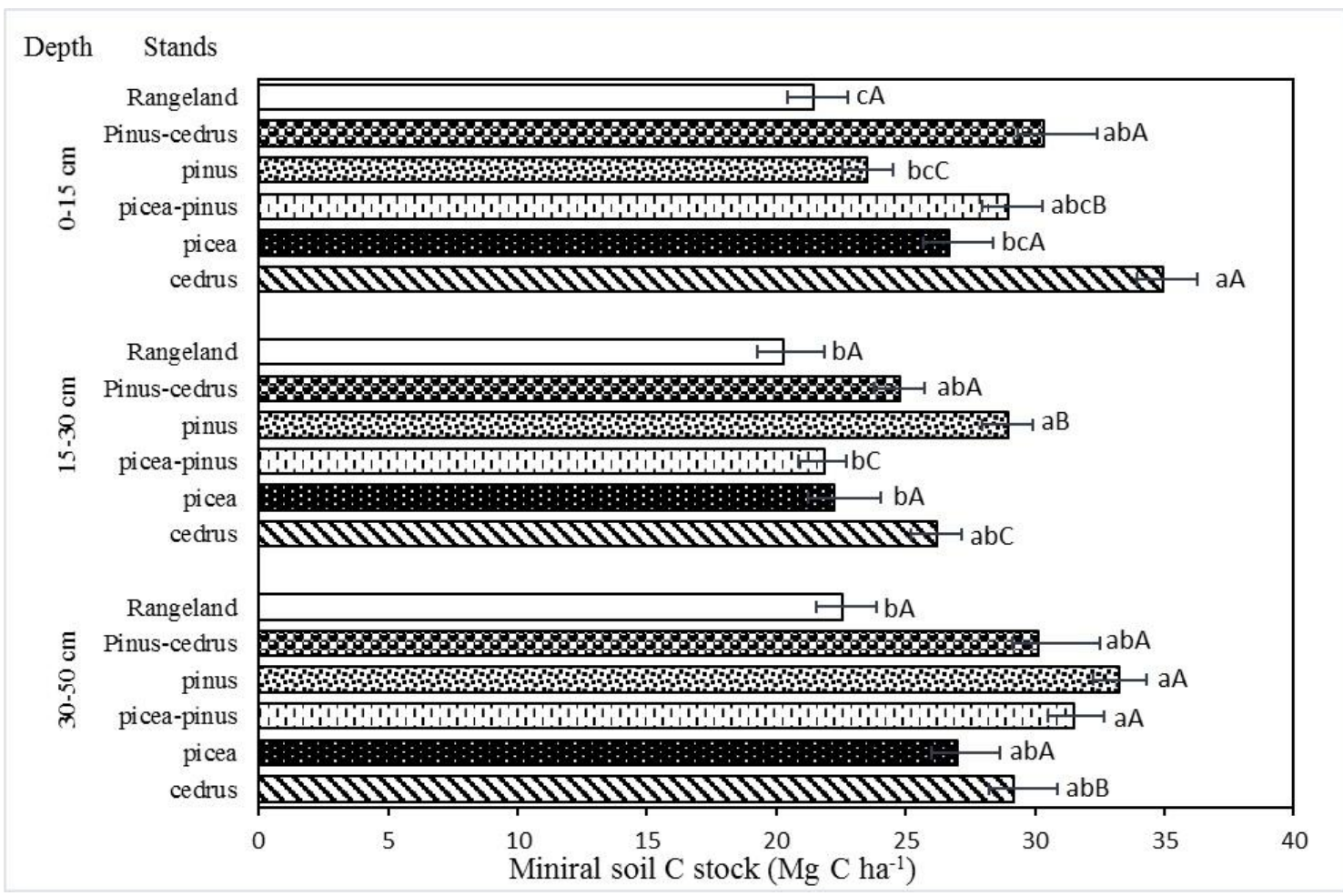

Figure 3. Distribution of $C$ stocks in mineral soil of stands (Mean $\pm S E)$. Different lowercase letters within each soil depth indicate the significant difference of mean values $(p<0.05)$ among the stands. Different capital letters within same stand indicate the significant difference of mean values ( $p<0.05)$ among the depths.

\section{Discussion}

Establishment of coniferous species on the degraded rangeland caused an increase in the carbon stock of ecosystem. Considering 20 years of establishment of coniferous 
species in the degraded rangeland, the amount of annual sequestration in the mixed $P$. nigra - C. libani, $P$. nigra, mixed $P$. abies - P. nigra, pure $C$. libani, and $P$. abies stands were $1.60,1.26,0.72,0.67,0.35 \mathrm{MgC} \mathrm{ha}^{-1} \mathrm{y}^{1}$, respectively.

One of the controversial issues was the proportion of the carbon stock in the soil and biomass (Uri et al., 2012). In this study, the contribution of soil in the carbon stock was higher than that of the other sections $(85.60,80.28,79.58,70.85,58.30$ and 51.11 in the P.abies, C.libani, P.abies - P.nigra, P.nigra, and P.nigra - C.libani stands, respectively). These results indicated the integral importance of soil in the carbon sequestration of ecosystem. Peltoniemi et al. (2004) expressed that a more significant amount of carbon was stored in the forest soils than in the forest biomass. Similar results were described by Garten and Charles (2002).

According to the EC / UN-ECE (2003), the carbon stock of forest soils in Europe was $1 / 5$ times more than that of the biomass. In contrast, other studies indicated the high proportion of biomass in the total ecosystem carbon stock (Uri et al., 2012; De Wit et al., 2006; Peichl and Arain, 2006). Conflicting results on the soil carbon stock could be due to the influence of various factors on this matter. It was apparent that the type of tree species affected the carbon stock by the amount and quality of organic matter input by litter, root activity and microclimate change (Jandl et al., 2007; Lugo and Brown, 1993).

Also, Osher et al. (2003) expressed that the change of soil carbon stock associated with land use changes is in relation to soil mineralogy. In our study, it was found that the type of tree species had a direct impact on the carbon stock in the mineral sector of soil. Furthermore, a significant correlation was found among the clay, clay- silt, and soil carbon stock (Fig. 4a, c), while a significant negative correlation was found between the percentages of sand and soil carbon stock (Fig. $4 b$ ).
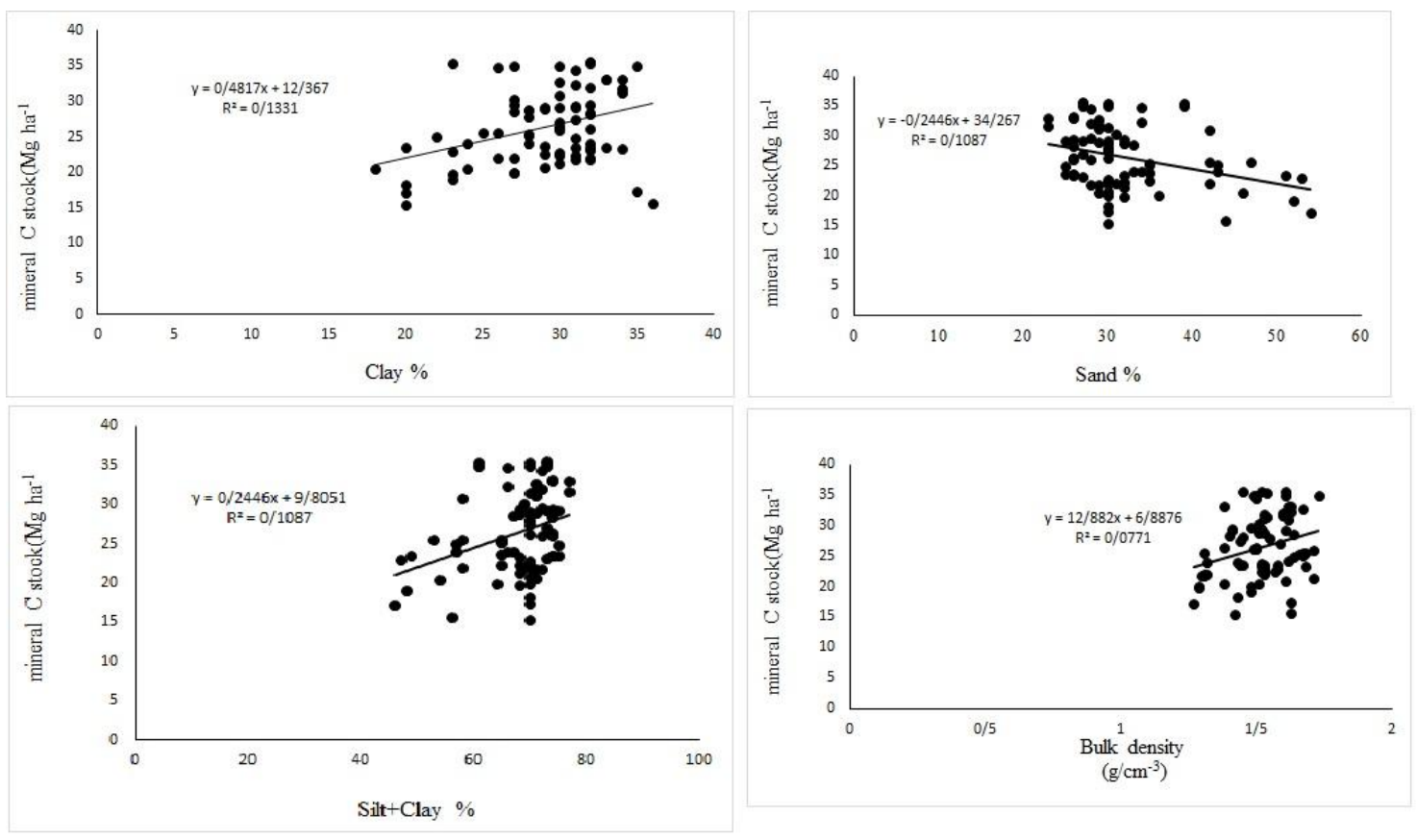

Figure 4. Correlation between C content $\left(\mathrm{Mg} \mathrm{ha}^{-1}\right)$ and soil textural (Clay, Clay+silt and Sand) and bulk density, all are significant in 0.001 level except bulk density in 0.05 level. 
Bauer et al. (1987) believed that the soil organic carbon was related to the clay of soil. Garten (2002), Powers (2002) and Matus et al. (2008) confirm our findings. They found that carbon sequestration correlated with the silt and clay of soil. A high percentage of sand in the spruce stand (Table 1) could be a more significant factor in the low carbon stock than the other stands. Rapid carbon aggregation and turnover in the coarse-grained soils (Richter et al., 1999) could be effective to decrease the soil carbon stock in the pure spruce stand (Fig. 2).

The clay and organic carbon were often formed as aggregate, and therefore they had much more affinity to bind organic matter compared to the sand (El Tahira et al., 2009). In this regard, Borchers and Perry (1992) observed that the concentration of organic matter was less in the sandy soils than in the clay and silt soils.

In this study, different distributions of the soil organic carbon were determined in the soil layers of considered stands (Fig. 2). The increasing trend of carbon stock was observable in the pure pine (Fig. 2). Such a trend was seen to augment the bulk density with the increase of depth in this stand (Table 1). In general, a positive correlation between bulk density and the soil carbon stock was found in this study (Fig. 3d).

However, the differences in the amount of sand, clay and silt in the different depths could be the reason of different carbon distribution in the soil layers. The differences among tree species in terms of root activity region had remarkable impacts on these differences. The root decompositions (especially thin roots) were important processes affecting the density and carbon stock (Steele et al., 1997).

$\mathrm{pH}$ was one of the main soil properties that affected the availability of the soil nutrients (Beery and Wilding, 1971), thus higher soil $\mathrm{pH}$ in the surface soil layer of $C$. libani stand than other stands could cause higher mineral carbon stock of soil.

Because there was a more appropriate condition for degradation in the surface layer of $C$. libani stand than the other stands which in turn increased the carbon stock in the higher levels of soil.

Thuille and Schulze (2006) noted the decrease of fauna activity of acidic soil which could also result in high carbon stock in the surface layer of pine - cedar stand.

The litter production and its degradation had a significant effect on the soil fertility (Pragasan and Parthasaratly, 2005) and it was considered as a notable factor by which tree species could affect soil organic matter (Finzi et al., 1998). The high carbon stock in the biomass and litter of mixed P. nigra - C. libani (Fig. 2) probably was due to the high canopy density of this stand compared to the other stands. (Table 1).

The litter resulted from trees were the main source of carbon in the forest ecosystems (De Marco, 2013) and the high density of canopy could be an integral source of litter and aboveground biomass in P. nigra - C. libani stand. In total, 40.21 percent of the total carbon stock was in the aboveground P. nigra - C. libani stand. Accordingly, development of root would increase by the increase of canopy. The highest belowground carbon stock included roots in P. nigra - C. libani stand had significant difference than the other stands and it possessed 8.67 percent contribution to total carbon stocks of ecosystem.

In this study, the properties of species in terms of growth of stem, branch, and leaf had significant impact on the rate of carbon accumulation in the above- and belowground biomass. In total, the amount of carbon accumulation in the coniferous ecosystems had significant increase in the degraded rangeland. 


\section{Conclusions}

Our study shows the potential of fast growing coniferous plantations in degraded rangelands to mitigate the effect of high $\mathrm{CO}_{2}$ concentrations over a short time span. Further knowledge was found during the calculation process and future research areas were suggested.

Coniferous plantations on degraded rangeland will most probably increase the rate of $\mathrm{C}$ sequestration and thereby mitigate the negative effects of increasing atmospheric $\mathrm{CO}_{2}$ concentrations. The sequestration rates will be affected by tree species, former land use, soil mineralogy, climate and management of the plantations. Those effects on $\mathrm{C}$ sequestration rates need further investigations and more long-term studies are desirable. Moreover we can say that the maintenance or increase in carbon stock of forests has been linked to economic and external benefits, such as climate change mitigation, biodiversity improvement, water storage and regulation of local climate at landscape level.

\section{REFERENCES}

[1] Akala, V.A., Lal, R. (2001): Soil organic carbon pools and sequestration rates in reclaimed minesoils in Ohio. - Journal of Environmental Quality 30: 2098-2104.

[2] Bauer, A., Cole, C.V., Black, A.L. (1987): Soil property comparisons in virgin grasslands between grazed and nongrazed management systems. - Soil Science Society of America Journal 51: 176-182.

[3] Beery, M., Wilding, L.P. (1971): The Relationship between Soil pH and Base-Saturation Percentage for Surface and Subsoil Horizons of Selected Mollisols, Alfisols, and Ultisols in Ohio. - Ohio J. Sci. 71:43-55

[4] Borchers, J.G., Perry, D.A. (1992): The influence of soil texture and aggregation on carbon and nitrogen dynamics in southwest Oregon forests and clear cuts. - Can. J. Forest Res. J. Can. Rech.Forest 22: 298-305.

[5] Bouyoucos GJ. (1962): Hydrometer method improved for making particle size analysis of soils. - Argon J 56: 464-465.

[6] De Marco, A., Esposito, F., Berg, B., Giordano, M., Virzo De Santo, A. (2013): Soil C and $\mathrm{N}$ sequestration in organic and mineral layers of two coeval forest stands implanted on pyroclastic material (Mount Vesuvius, South Italy). - Geoderma 209-210: 128-135.

[7] De Wit, H.A., Palosuo, T., Hylen, G., Liski, J. (2006): A carbon budget of forest biomass and soils in southeast Norway calculated using a widely applicable method. - Forest Ecology and Management 225: 15-26.

[8] EC/UN-ECE, de Vries, W., Reinds, G.J., Posch, M., Sanz, M.J., Krause, G.H.M., Calatayud, V., Renaud, J.P., Dupouey, J.L., Sterba, H., Vel, H.M., Dobbertin, M., Gundersen, P., Voogd, J.C.H. (2003): Intensive monitoring of forest ecosystems in Europe, 2003. Technical report. EC/UN-ECE 2003, Brussels, Geneva (p. 163).

[9] El Tahira, B.A., Ahmedb, D.M., Ardo, J., Gaafard, A.M., Salih, A.A. (2009): Changes in soil properties following conversion of Acacia senegal plantation to other land management systems in North Kordofan State, Sudan. - Journal of Arid Environments 73 : 499-505.

[10] Fataei, E., Varamesh, S., Behtari, B., Seyyed Safavian, S.T. (2013): Soil Carbon and Nitrogen Stocks under Pinus nigra and Cedrus libani afforestation in the Northwestern Highlands of Iran. - Advances in Environmental Biology 7(13): 4316-4325.

[11] Finzi, A.C; Canham, C.D; van Breemen, N. (1998): canopy tree soil interactions within temperature forests: species effects on $\mathrm{pH}$ and cations. - Ecological Applied 8: 447-454. 
[12] Garten Jr., C. T. (2002): Soil carbon storage beneath recently established tree plantations in Tennessee and South Carolina, USA. - Biomass and Bioenergy 23 ( 2): 93-190.

[13] Giuffre L., Heredia O., Pascale C., Cosentino D., Conti M., Schnug E. (2003): Land use and carbon sequestration in arid soils of northern Patagonia (Argentina). Landbauforschung Volkenrode 53(1): 13-18.

[14] Gower, S.T. (2003): Patterns and mechanisms of the forest carbon cycle. - Ann. Rev. Environ. Resour. 28: 169-204.

[15] Grunzweig, J.M., Lin, T., Rotenberg, E., Schwartz, A., Yakir, D. (2003): Carbon sequestration in arid-land forest. - Global Change Biology 9: 791-799.

[16] Gucinski, H., Vance, E., Reiners, W.A. (1995): Potential effects of global climate change. - In: Smith, W.K., Hinckley, T.M. (Eds.) Ecophysiology of Coniferous Forests. Academic Press, New York, Chapter 10, pp. 309-331.

[17] Guo, L.B., Gifford, R.M. (2002): Soil carbon stocks and land use change: a meta analysis. - Global Change Biology 8, 345-360.

[18] Hansson, K., Fröberg, M., Helmisaari, H.S., Kleja, D.B., Olsson, B.A., Olsson, M., Tryggve, P. (2013): Carbon and nitrogen pools and fluxes above and below ground in spruce, pine and birch stands in southern Sweden. - Forest Ecology and Management . (in press). http://dx.doi.org/10.1016/j.foreco.2013.05.029.

[19] Hernandez, R., Koohafkan, P., Antoine, J. (2004): Assessing Carbon Stocks and modeling win-win Scenarios of carbon sequestration through land-use changes. - Food and Agriculure Organization, p.166.

[20] Houghton, R.A. (2005): Aboveground forest biomass and the global carbon balance. Global Change Biol. 11: 945-958.

[21] IPPC, 2000. Land use, Land-Use Change And Forestry. - Cambridge University Press, Cambridge, 375 pp.

[22] IPCC, 2001. Climate change Mitigation. http://www.grida.no/climate/ipcc_tar/wg3/pdf/TAR-total.pdf.

[23] Jandl, R., Lindner, M., Vesterdal, L., Bauwens, B., Baritz, R., Hagedorn, F., Johnson, D.W., Minkkinen, K., Byrne, K.A. (2007): How strongly can forest management influence soil carbon sequestration? - Geoderma 137: 253-268.

[24] Kumar, S., Datta, R., Sinha, S., Kojima, T., Katoh, S., Mohan, M. (2001): Carbon stock, afforestation and acidic deposition: an analysis of inter-relation with reference to arid areas. - Water, Air, and Soil Pollution 130: 1127-1132.

[25] Lemma, B., Berggren, D., Nilssonc, I., Olsson, M. (2006): Soil carbon sequestration under different exotic tree species in the southwestern highlands of Ethiopia. - Geoderma $136: 886-898$.

[26] Lugo, A.E., Brown, S. (1993): Management of tropical soils as sinks or sources of atmospheric carbon. - Plant Soil 149: 27-41.

[27] Maestre, F.T., Cortina, J. (2004) : Are Pinus halepensis plantations useful as a restoration tool in semiarid Mediterranean areas? - Forest Ecology and Management 198: 303-317.

[28] Matus, F. J., Lusk, C. H., Maire, C. R. (2008): Effects of soil texture, carbon input rates, and litter quality on free organic matter and nitrogen mineralization in Chilean rain forest and agricultural soils. - Communications in Soil Science and Plant Analysis 39: 187-201.

[29] McDicken, K. G. (1997): A Guide to Monitoring Carbon Storage in Forestry and Agro forestry Projects. - Winrock International Institute for Agricultural Development, Forest Carbon Monitoring Program. pp: 91.

[30] Mireia, L., Bruno, G.M., Belén, T. (2010): Storage of organic carbon and black carbon in density fractions of calcareous soils under different land uses. - Geoderma 159: 31-38.

[31] Nosetto, M.D., Jobbágy, E.G., Paruelo, J.M. (2006): Carbon sequestration in semi-arid rangelands: Comparison of Pinus ponderosa plantations and grazing exclusion in NW Patagonia. - J. Arid Environ. 67: 142-156. 
[32] Osher, L.J., Matson, P.A., Amundson, R. (2003): Effect of land-use change on soil carbon in Hawaii. Biogeochemistry 65:213-232.

[33] Paul, K. I., Polglase, P. J., Nyakuengama, J. G., Khanna, P. K. (2002): Change in soil carbon following afforestation. - Forest Ecology and Management 168: 241-257.

[34] Peichl, M., Arain, M. A. (2006): Above- and belowground ecosystem biomass and carbon pools in an age-sequence of temperate pine plantation forests. - Agricultural and Forest Meteorology 140: 51-63.

[35] Peltoniemi, M., Makipaa, R., Liski, J., Tamminen, P. (2004): Changes in soil carbon with stand age-an evaluation of a modelling method with empirical data. - Global Change Biol. 10:2078-2091.

[36] Powers, J.S., Schlesinger, W.H. (2002): Relationships among soil carbon distributions and biophysical factors at nested spatial scales in rainforests of northeastern Costa Rica. Geoderma 109(3-4):165-190.

[37] Pragasan, L.A; Parthasarathy, N. (2005): Litter production in tropical dry evergreen forests of south India in relation to season, plant life forms and physiognomic groups. CURRENT SCIENCE, VOL. 88, NO. 8: 1255-1263

[38] Richter, D.D., Markewitz, D., Trumbore, S.E., Wells, C.G. (1999): Rapid accumulation and turnover of soil carbon in a re-establishing forest. - Nature 400: 56-58.

[39] Steele, S.J., Gower, S.T., Vogel, J.G., Norman, J.M. (1997): Root mass, Root mass, net primary production and turnover in aspen, jack pine and black spruce forests in Saskatchewan and Manitoba, Canada. - Tree Physiol. 17:577-587.

[40] Thuille, A., Schulze, E.D. (2006): Carbon dynamics in successional and afforested spruce stands in Thuringia and the Alps. - Global Change Biology 12: 325-342.

[41] Uri, V., Varik, M., Aosaar, J., Kanal, A., Kukumägi, M., Lõhmus, K. (2012):Biomass production and carbon sequestration in a fertile silver birch (Betula pendula Roth) forest chronosequence. - Forest Ecology and Management 267: 117-126.

[42] United Nations Framework Convention on Climate change (UNFCCC). 1997. Kyoto protocol to the UnitedNations framework convention on climate change. Available on the Internet: http://unfccc.int/resource/ docs/convkp/kpeng.htlm.

[43] Varamesh, S., Hosseini, S.M, Abdi, N., Akbarinia, M. (2010): Effects of afforestation on Soil Carbon Sequestration in an Urban Forest of arid zone in Chitgar forest park of Tehran. - Forest Science 3: 75-90.

[44] Varamesh, S., Hosseini, S.M., Abdi, N. (2011): Estimating Potential of Urban Forests for Atmospheric Carbon Sequestration. - Journal of Environmental Studies 37 (57): 113-120.

[45] Varamesh, S., Hosseini, S.M., Keivan Behjou, F., Fataei, E. (2014): The impact of land afforestation on carbon stocks surrounding Tehran,Iran. - Journal of Forestry Research 25(1): 135-141.

[46] Watson, R.T. (2000): Land Use, Land-Use Change, and Forestry: A Special Report of the IPCC. - Cambridge University Press, Cambridge, p. 377.

[47] Xiao-Wen, D., Shi-Jie, H., Yang-Ling, H., Yu-Mei, Z. (2009): Carbon and nitrogen transformations in surface soils under Ermans Birch and Dark coniferous forests. Pedosphere 19(2): 230-237.

[48] Yüksek, T., Yüksek, F. (2011): The effects of restoration on soil properties in degraded land in the semi-arid region of Turkey. - Catena 84:47-53.

[49] Zhang, C., Liu, G., Xue, S., Sun, C. (2013): Soil organic carbon and total nitrogen storage as affected by land use in a small watershed of the Loess Plateau, China. - European Journal of Soil Biology 54: 16-24.

[50] Zinn, Y.L., Resck, D.V.S., Silva, J.E. (2002): Soil organic carbon as affected by afforestation with Eucalyptus and Pinus in the Cerrado region of Brazil. - Forest Ecology and Management 166: 285-294. 